\title{
Abuse of Law Doctrine in Tax Law
}

\section{Viola Tanto}

PhD Cand. Tax Law, European University of Tirana

\section{Abstract}

This paper was written in order of the reforming of the tax system's framework. Analysing phenomena such as tax evasion, tax avoidance, the use of legal loopholes to reduce tax liability in Italy was very challenged. The purpose of this paper is to verify, in the light of most interventions the latest case law of the European Court of Justice, if it exists in the field of direct and indirect taxes, a general principle of abuse of law. The existence of this provision will be analyzed in the context of the principle of legal certainty. We should analyse the concept of abuse of law as a normative problem and historical-evolutionary phenomenon. In this paper a special place is taken by the genesis of the concept of abuse of Community law and the general principle of prohibition of abuse of the right in function of a general anti-avoidance norm, its meaning, effects and role as a corrector of the system. We have addressed the role of jurisprudence of the European Court of Justice, dividing it into two parts: Abuse in field of harmonized taxation- Halifax Doctrine and Abuse in the field of disharmonized taxation -The leading case-Cadbury Schweppes.

Keywords: tax system, tax avoidance, doctrine of abuse of law, re-characterization.

\section{Introduction}

\section{$1.1 \quad$ Methodology}

Every serious research requires, first of all, the definition of the methodology that will be used for its realization and for the drawing of conclusions. The method of study is closely related to the chosen field of study, as the method above all must be appropriate to the field of study and the results required to be achieved. The methodology used for all the key issues addressed in this paper is largely qualitative. This paper also includes comparative methods on specific aspects of the paper. The main methodological principle in legal comparison is that of functionality, namely "la in law the only things which are comparable are those which fulfill the same function". Based on the above analysis, the methodology used to carry out this paper is presented as follows.

Doctrinal research (collection and processing of the literature). This phase consists of reviewing the literature related to the object of study, which includes the identification, collection and systematization of books, monographs, schientific articles, papers of national and international conferences in the legal field. The selection of literature is spread over a relatively considerable number of foreign authors as well as some local authors.

Analysis of the legislation. In achieving certain objectives in this paper we have relied on the method of analysis and synthesis. This method consists in formulating legal problems through 
the analysis of legislation. In our legal system, legal norms are found in codes, laws and other acts. Since norms regulate general situations, the method of legal analysis serves to identify and solve problems of theory and practice, through the interpretation of these norms. Also, this method serves to clarify the ambiguity of norms, their placement in a logical and coherent order and to analyze their interaction other norms.

Comparative method. For a better understanding and interpretation of domestic legal norms, the realization of a comparative analysis between the domestic tax legislation and the legislation of those countries (Italian legislation), which has served as a model for Albanian legislation.

The method of analysis of case law is also a very important method, which serves to see the way of interpretation and practical application that Albanian and foreign courts have made to tax evasion and the doctrine of abuse of law. The analysis of the practice of foreign courts serves to see the way of interpretation and practical application of tax evasion by these courts, in order to have a better understanding of tax evasion and the methods of its ascertainment by the Albanian courts.

Quantitative method. During the work were reflected statistical data of criminal offenses in the field of taxes published in the official Annual Reports of the GDT. These data show an increase, year after year, in the number of criminal offenses in the field of taxation in Albania. As no statistical study of tax evasion has been conducted in Albania, this is one of the limitations of this paper.

\subsection{Abuse of law concept}

In recent years in European countries has been assisted in a process of deterioration of the national tax system. The reasons for this deterioration are various, but the specific weight is attributed to the constant normative change, conditioned by the conditions and emergency needs, which make these adjustments not systematically coordinated with the existing adjustment and the difficulty of the tax administration in interpreting cases. concrete evasion by taxpayers of tax liabilities [1].

In this context the abuse of right has arisen as a margin against these transactions aimed at gaining tax advantages. Until the 1990s, it was claimed that there was no general antiavoidance norm in Italian legislation; the response to avoidance was entrusted to a number of specific anti-avoidance norms, which defined the types of behaviors that would be considered avoidance and therefore their effects were not recognized.

Therefore, it was considered a novelty the introduction of a general anti-avoidance norm [1], represented by article 10, of law no. 408/1990, which although limited its application to only a few cases, defined as avoidance all transactions carried out with the sole purpose, that of gaining tax advantages illegally.

In the late '90s, according to Palumbo in his book "Elusione fiscale e abuso del diritto, L'aggiramento degli obblighi impositivi tra legittimo risparmio ed evasione fiscale", stated that changes were made again, which consisted of the reformulation of this notion from article 37bis of Presidential Decree (P.S) no.600, and aimed not at modifying the existing approach, but clarifying the concept of fraudolenza-dishonesty (illegality). This concept did not necessarily have to correspond to the criminal meaning of this term, in order to gain tax advantages, but it referred to all those actions, acts, transactions, related to them, that lacked valid economic 
reasons, with direct impact in the deviation of obligations or prohibitions provided by tax legislation, and in order to achieve reductions in tax liabilities or their refunds.

In this way, the intention of the legislator to individualize a discipline similar to the civil one, provided by Article 1344 of the Italian Civil Code, on contracts in fraud (Contratto in frode alla legge).

As in civil law, are considered fraudulent law, actions which are defined as means to avoid the application of an orderly norm, using not simulation, but the objective elements of the contract in a particular way; as well as in tax law, constitutes a transaction in fraud of tax rates, the one who does not directly violate this rate, but avoids the "aggression" from the obligation or prohibition established, thus gaining advantages and thus violating the principle of the tax system. on solvency according to Palumbo.

It is necessary that the basic principles of tax law have been violated, that the behavior of the taxpayer be considered as evasion [2]. These principles are e.g. prohibition of double cost reduction, prohibition of tax increase, etc.

The Court of Cassation changed the line of argument developed in 2005, which focused on invalidity due to defect or illegality of cause, on contracts signed for fiscal purposes (dividend washing and dividend stripping contracts).

In conclusion, the following considerations can be formulated according to Palumbo analysis:

* There is no doubt that tax legislation should be able to identify and address the elusive behaviors of taxpayers even when they become overly sophisticated.

* It should be borne in mind that this reaction by the tax administration to oppose evasion cases should not be transformed into ad nutum non-application of written rules.

* Abuse of the right is evident in transactions carried out by taxpayers without valid economic reasons, to achieve tax advantages, where judging or testing valid economic reasons is done ex post, and is therefore extremely difficult both from the point of view of the burden of proof, as well as in terms of normative lack.

In order to determine the abuse of the right, in each case, the complex content of the transaction must be analyzed, which is formally in accordance with the normative definitions, but not substantially.

\section{Law as facultas agendi: l'abus de droit}

Abuse of the law, in the experience of countries part of the Civil Law legal family, has existed for almost a century and a half, when it first appeared in the liberal legal order of the second half of the 1800s, as an incorrect exercise of subjective right [2].

Otherwise it can be called as abuse of a facultas agendi, ie the exercise of individual and collective freedoms, in economic relations, applying the principle that what is not forbidden is allowed ${ }^{1}$.

From the liberal point of view, subjective right was considered as the prerogative of the individual, as the recognition of his freedom. The crisis of the institutional principles of liberal

\footnotetext{
${ }^{1}$ Qui suo iure utitur neminem laedit "and“ nullus videtur dolo facere suo iure utitur”.
} 
societies and legal positivism (formal equality before the law) favored the birth and spread of the theory of abuse, which was a correction of the absolute declaration of real rights. Thus, the abuse of the right became a means of substantive control, of the discretion of the free exercise of private autonomy and developed in parallel, with the progressive expansion of legal forms of control in private law.

The modern theory of abuse of law consolidated the social responsibility of the legal order, thanks to the contribution of French doctrine and its codification. Rights have a social purpose, are relative and their exercise beyond their economic and social function constitutes abuse.

Through the prohibition of abuse the social function of law is achieved. The traditional definition of abuse includes the hypothesis of using or not using a right, which does not bring advantages in itself, but aims to create these advantages for others.

The object of abuse, in fact, is not limited to subjective rights in the narrow sense. The notion of abuse according to Piantavigna represents the means to determine the scope and limits of the subjective legal position of complex tax advantages.

The object of abuse can be positions that constitute an advantage (facultas agendi) or normative provisions (norma agendi). The second object is abuse in the broad sense, to distinguish it from what we have just explained, abuse in the narrow sense, (facultas agenda) as the first form of abuse.

The concept of frode alla legge (in deception of law) is one of the forms of abuse of law: the conceptual assimilation of two legal figures comes from the fact that abuse is often described as illegal use of the norm, which is avoided ratio (purpose).

Even the concept of frode alla legge, like abuse in the narrow sense, is a concept which arises in the field of civil law and is presented as an instrument of a hybrid character, produced by a long process of technical cleansing.

This concept provides a "bypass" of legal rules: the taxpayer abuses the freedom to adopt a certain treatment of his interests, using the variety of legal forms that the legal order makes available, in order to achieve a result, which usually, the legal system does not allow and indirectly does not approve [2]. The core of this concept is represented by the norm avoidance activity, which according to the principles should be applied and not by social harm; the element of causing harm is no longer so essential in the configuration of abuse.

\section{The genesis of the concept of abuse in Community law}

The course and problematics of the categories of tax evasion and abuse of tax law take on other characteristics in the international context. In international law, the principle of abuse arises [2] with the fading of the dogma of sovereignty and the recognition of the fact that states are subject to law, even when not created by agreement.

The problem of abuse of law constitutes an exigency for correction and development, which is existing in every legal order [3].

Community law (EU law) also considers the phenomenon of abuse as a priority. This seems to be the source of a nearly thirty-year-old jurisprudence of the European Court of Justice that has legitimized itself to oppose the presence of abusive behavior, even in the absence of a norm that explicitly defines this authority, both in the community order and in the national one. 
Moreover, the genesis of the concept of abuse of law is explained precisely by the reason of the destructive normative context, typical of the European legal order [2].

The European legal system is an self-sufficient and complete system, for which the fact of the absence of an explicit norm is irrelevant, while the way of its evolution is completely original. Precisely due to the less developed character of the community legal system compared to the national one, a continuous exchange of experiences and legal institutes has been delegated between the member states (in the horizontal sense) and between them and the community system (in the vertical sense).

National legislation contributes to the realization of the completeness of the legal system, which represents the necessary criterion within the framework of effectiveness, without being hindered by the principle of uniformity. The principles elaborated by the ECJ, create starting points for future legal elaboration [3].

Luxembourg judges elaborate general principles as sources of law, thanks to the combined effect of fundamental principles, uniformity and the direct effect of Community law: "soft law" or soft law represented by common principles and values, is transformed by the European Court of Justice into a "hard law", through the creation of judicial rules and compulsory export at the European level. In this return, where national legislation is "permeable" by the interpreted Community law, the general principles elaborated by the Court tend to be affirmed as values disseminated by the Community legal system. Thus, the system of community principle [2] adopted by the court, does not have an external origin, but it is a matter of principles of community law, with all legal effects, which are not "borrowed" from other legal systems.

It is interesting to observe how, according to this new provision, the elusive phenomenon is expressly traced back to the concept of abuse of the right: a broad notion, repeatedly investigated by doctrine and jurisprudence, which indicates the anomalous exercise of a right which, without realizing any valid and concrete interest for its owner, it causes damage or a danger of damage to other subjects, thus placing itself in radical contrast with the purpose in view of which that right was attributed by the law.

Before the introduction of the aforementioned art. 10-bis, the phenomenon of tax avoidance was contemplated by art. 37-bis of the D.P.R. 600/1973, as part of the provisions on the assessment of income taxes. As a result of the 2015 news, this provision was repealed and any reference to it must now be understood as referring to the current art. 10-bis L. 212-2000.

According to paragraph 1 of the new art. 10-bis, "one or more transactions without economic substance which, despite formal compliance with tax regulations, essentially achieve undue tax advantages constitute abuse of the right". Consequence of the recognized abusive nature of a transaction is its non-enforceability to the financial administration, therefore entitled to disregard the advantages and therefore to determine the taxes due "on the basis of the rules and principles evaded and taking into account the amount paid by the taxpayer as a result of these operations".

The definition provided, rather generic in its outlines, is better specified by the following paragraph 2, according to which we consider:

“a) transactions without economic substance, facts, deeds and contracts, even connected to each other, unsuitable for producing significant effects other than tax advantages. In 
particular, the non-coherence of the qualification of the individual transactions with the legal basis of the whole and the non-compliance of the use of legal instruments with normal market logic are indices of lack of economic substance;

b) undue tax advantages the benefits, even if not immediate, realized in contrast with the purposes of the tax laws or with the principles of the tax system ".

A further clarification - this time in the negative - is provided in the third paragraph of the provision, where it is pointed out that "in any case, the operations justified by valid extra-fiscal reasons, not marginal, also of an organizational or managerial nature, which respond for the purpose of structural or functional improvement of the company or of the taxpayer's professional activity".

\section{The concept of avoidance. In what sense is tax avoidance illegal?}

Tax avoidance involves arranging a transaction or series of transactions in such a way as to gain a tax advantage, distinguishing between tax planning, which is lawful, and tax evasion.

Increasing cases of avoidance must be addressed and urgent and concrete measures must be taken. This poses a serious challenge to the effectiveness of tax laws.

Throughout the multitude of books, articles or reports on this subject have been observed contradictions and different streams of opinion on the nature and causes of tax evasion, ways of responding to it or addressing it, mentioning the fact that for some authors tax evasion is a problem which requires an answer on the part of the legislature [4]. Exactly this is the role of the science of law, that of studying the balances between socio-economic developments and the law, as well as that of interpreting the law in function of these changes.

The divergences in these views of different groups of scholars, doctrine or jurisprudence come as a result of the legal traditions of states pertaining to the rights and obligations of the individual in tax law.

The problems faced by the Italian system and other tax systems of the OECD member states have been numerous. Sometimes legal changes have tended to reflect a pragmatic approach, which solved only a part or none of the problems of the tax system. The main issues and the most vulnerable areas which have been and continue to be problematic for Italy as well as for other countries, including the Albanian case, are:

- lack of a clear and coherent policy to address the structural choices provided by tax legislation;

- the fact that the tax system exists as an economic reality in the business world and as a real and substantial cost that affects the form of most transactions;

- the existence and application of many formal principles for characterizing transactions and creating differences, which are more formal than substantial;

- different tax for different businesses and the lack of a coherent income tax framework.

The ways that have been followed to ascertain tax evasion have been different. In Italy, the interpretation of an anti-evasion provision has been used mainly, as to whether or not this provision constitutes a general anti-evasion rule, which would facilitate the process of tax evasion by the tax administration. 
Referring to the Italian legislation, in this paper it will be determined that the general antiavoidance rules are essentially "unclear" in their scope and application. The approach to a legal interpretation, within the scope of the legislation serves as a guide to understand and apply tax evasion and to provide a more complete and effective solution to the problem of tax evasion. The tendency to avoid, although ethically reprehensible, is considered a natural human behavior. The human being is in fact an "economic entity", which as such tends to perform those actions which require a minimum of investment, to achieve maximum profit. Also, according to [5] each entity operates on the basis of a cost-benefit calculation and aims at the minimum use of capacity, in our case, property.

From the economic point of view, again this kind of behavior is natural, while from the legal point of view, tax avoidance is an inadmissible phenomenon, because it is contrary to the principles of tax law and cause obvious and substantial "distortions", as in the economic plan, as well as in the social one [6].

In fact, there is not yet a complete definition of tax avoidance and the impact of the concept of abuse of law has made the exact individualization of this definition even more complex. Not only the concept of abuse of law [7], as the most innovative in tax law, but also cases of similarity with tax evasion, simulation, tax planning make tax avoidance, difficult to identify and ascertain.

However, as we will see in the following, from a detailed treatment, tax evasion differs from the above cases, both in form and content [8].

By tax evasion, according to [8] we will understand the situation when income is declared, but transactions are structured in such a way, using the legal space, that the tax liability is reduced. This reduction has not been in the intention of the legislator nor in the spirit of the law [7].

During the century XX, many cases of tax avoidance in Italy have been ascertained only with the use of some specific measures in specific sectors, which seemed more vulnerable to abusive cases. Attempts to formulate a general anti-avoidance rule ran counter to the principle of contractual autonomy and legal certainty. The real concern was that, if the tax administration were to be given the right to assess the effective link between the form of the transaction, [8] the substance and the economic result obtained by the parties, the improvement could have been worse, than the problem itself. In fact, the tax administration is not an impartial third party and its "power" facilitates the regulation of this problem [9].

In tax law, it is often difficult to distinguish between tax evasion, tax avoidance and legal savings or, as it is otherwise called, tax planning. Avoidance is in an intermediate position between tax evasion (or open violation of the normative provisions of tax law) and legitimate austerity (as a lawful exercise of the contractual freedom and autonomy of the parties).

Thus, avoidance consists in using the rules in an instrumental way, formally perfect, but which is essentially contrary to the spirit of the provisions, aiming, exclusively or mainly, at reducing the tax burden normally payable. According to [8]The taxpayer, who under normal circumstances would be subject to a special tax regime, avoids the application of the latter, fulfilling one or more transactions, which otherwise would not performed, or acts artificially under the conditions required by law, in order to enjoy a more favorable position, contrary to the purposes set by the law itself [8]. 
In an attempt to further clarify these two concepts, legal doctrine has attempted to highlight the essential features of tax avoidance. There are always four elements present in a tax avoidance case, which are:

Anomalies of the transaction compared to the type of transaction that would normally have been performed, in the same or similar circumstances;

The tax advantage achieved through the unusual transaction, compared to what the taxpayer would normally benefit from;

Adjustment of the transaction in accordance with achieving the reduction or reimbursement of the tax liability;

The exclusive (or prevalent) goal, which leads the parties to deviate from the normative determination. For the first and last characteristic (objective and subjective elements, respectively), the tax administration will have to analyze case by case the real reasons they have caused the taxpayer to deviate from performing the ordinary transaction [10]. While for the other two to re-evaluate the amount of the obligation paid less.

\section{Conclusion}

In terms of globalization and the transferability of factors of production, direct taxes constitute a tax area where countries develop competition among themselves to be more attractive to foreign investors. The harmonization of the Albanian tax legislation with that of the European Union is in an ongoing process. Considering the fact that at the moment when Albania receives the status of candidate country for membership in the European Union, indirect taxes go towards harmonization, Albania must remain competitive in the field of direct taxes.

In this paper was analyzed, reviewed and compared the concept of tax evasion in Italian legislation and in Albanian legislation. From the analysis of doctrine, normative predictions and jurisprudence some important conclusions were reached.

Starting with the Albanian tax legislation, it was concluded that there is a general antiavoidance norm which needs changes, in order to increase the effectiveness of this rate, as a legal basis for addressing tax avoidance.

There are set out three criteria that must be met in order to determine the existence of a tax avoidance transaction:

(A) lack of valid business purpose;

(B) evasion of obligations or prohibitions;

(C) tax advantage (Benefit-reduction or refund of taxes).

From the analysis we performed, we can give a definition of the concept of tax avoidance. We are in the case of tax avoidance, when the taxpayer artificially creates the conditions for conducting a transaction which deviates from the normative determination by using the legal space, illegally, with the main or exclusive purpose - that of achieving a tax advantage.

Tax avoidance is in an intermediate position between tax evasion (open violation of normative provisions of tax law, failure to declare data and / or falsify them) and legitimate savings (tax planning as a lawful exercise of freedom and contractual autonomy of parties). The burden of the tax administration (as a third party), in these cases is to individualize the physiological 
transaction that the taxpayer should have performed and the effects (of the advantage gained) that he has received from performing the transaction without valid economic reasons. Once the administration identifies this type of transaction, it must reclassify it by imposing the highest tax resulting from this requalification [8].

Contesting abuse can be divided into three stages:

a) Individualization of the abusive transaction

b) Reclassification of the abusive transaction

c) Determining the tax effects of income (not recognizing the advantages achieved).

The legal order with its operators, on the one hand the tax administration and on the other hand the court, must not allow legal norms to be circumvented, or used in that form, in order to achieve illegal tax advantages.

As far as the Albanian case is concerned, as mentioned, efforts are still needed to develop a consolidated doctrine and jurisprudence, which will have a simpler path in the case of a general written community principle. Until 2019, in the Albanian legal reality, the only way to ascertain tax evasion is Article 71/dh of the law "On tax procedures", which provides for the right of the tax administration to re-evaluate the transaction or related transactions without essential economic substance". In 2019, the first general anti-avoidance norm was introduced, amending Article 71 of Law no. 9920/2008 "On tax procedures", as amended.

The implementation of indirect audit methods in Albania should be carefully managed. This approach is well accepted in international good practices, but for Albanian taxpayers and courts it will be a new experience. Auditors should be well trained in the application of indirect audit methods and given guidance detailed procedural. The first cases must undergo rigorous quality assurance reviews before a final assessment can be made.

Approximate estimates using indirect audit methods should be reasonable and non-arbitrary. The law should clearly authorize the use of indirect audit methods by the tax administration and reverse or reverse the burden of proof when the approximate tax assessment is based on indirect audit methods. The burden of proof is placed on the taxpayer specifically as to the adequacy of the recalculated tax base in such situations. Despite this, courts in many jurisdictions have ruled that the administration should make sincere efforts to determine the taxpayer's income, i.e. it simply cannot assign an abstract figure. A rough estimate of the taxpayer's income should be based on reasonable grounds and should also take into account the taxpayer's specific circumstances.

\section{References}

\section{Doctrine}

[1] G. Palumbo, Elusione fiscale e abuso del diritto, L'aggiramento degli obblighi impositivi tra legittimo risparmio ed evasione fiscale, Milano: Cesi Multimendia, 2011.

[2] P. Piantavigna, Abuso del diritto fiscale nell' ordinamento europeo, Torino, 2011.

[3] F. Losurdo, Il divieto dell'abuso del diritto nell' ordinamento europeo, 2011.

[4] Lavoisier, L'abuso di diritto nell'ordinamento tributario italiano., 2009.

[5] P. Locchi, La notificazione degli atti tributari, Come evitare errori procedurali, Republica 
di San Marino: Maggioli Editore, 2011.

[6] B. K. Broën, A comparative look at regulation of corporate tax avoidance, Comparative prespectives on law and justice, Italy: Springer edito, 2012.

[7] D. Terracina, Riflesi penali dell' evasione fiscale, Tra ricchezza nascosta e regime del dichiarato, Romë: Dike Giuridica Editrice, 2012.

[8] L. Antonini, Equivalenza di fattispecie tributarie ed elusione di imposta, Riv. dir. fin., 1966.

[9] E. Galdieri, General anti-avoidance rules \& doctrines, EUCOTAX Wintercourse, Roma: Facoltà di Giurisprudenza, Cattedra di Diritto Tributari, 2009.

[10] Gorezi, "In Shareholder Rights, Executive Compensation an Stakeholder Protection: a Comparative Overview of USA and chosen EU jurisdictions," CEU ETD Press, 2011.

[11] Mateli, Sistemi Tatimor në Shqipëri, Tiranë: Botimet Male, 2013.

[12] H. Lyon, Principles of Taxation, SHBA: Franklin Classics, 2019.

\section{Legislation of the Republic of Albania}

[1] Agreements ratified by the Assembly "On the avoidance of double taxation and the prevention of tax evasion", which are in force.

[2] Decision of the Council of Ministers, no. 818, dated 26.11.2014.

[3] Decision of the Council of Ministers, no.157, dated 15.3.2006.

[4] Decision of the Council of Ministers, no.33, dated 29.1.2014

[5] Decision of the Council of Ministers, no.430, dated 28.6.2006.

[6] Decision of the Council of Ministers, no.591, dated 10.9.2014.

[7] Law no. 131/2015, "On the National Business Center". changed

[8] Law no. 49/2012, "On the organization and functioning of administrative courts and adjudication of administrative disputes", as amended.

[9] Law no. 7638 dated 19.11.1992, "On trade companies".

[10] Law no. 7850, dated 29.7.1994, "On the Civil Code of the Republic of Albania" as amended.

[11] Law no. 7895, dated 27.7.1995, "On the Criminal Code of the Republic of Albania". changed

[12] Law no. 8438, dated 28.12.1998, "On income tax", as amended.

[13] Law no. 87/2019, dated 18.12.2019 "On the invoice and the circulation monitoring system", published in the Official journal No. 3, dated 20.01.2020

[14] Law no. 9136, dated 11.9.2003, "On the collection of compulsory social and health insurance contributions in the Republic of Albania", as amended 
[15] Law no. 92/2014, "On value added tax in the Republic of Albania". changed

[16] Law no. 92/2014, dated 28.12.2014, "On value added tax", as amended.

[17] Law no. 9920, dated 19.5.2008, "On tax procedures in the Republic of Albania", as amended.

[18] Law no.9723, dated 3.5.2007, “On the National Registration Center" amended.

[19] Law no.9754, dated 14.6.2007, "On criminal liability of legal entities".

[20] Law no.9901, dated 14.4.2008, "On traders and companies"

[21] The Constitution of the Republic of Albania, approved by law no. 8417, dated 21.10.1998, as amended. 